\title{
BOJANA MaLtarić
}

\section{ZAGREBU IZŠLA NOVA SLOVNICA ČEŠČINE}

COBISS: 1.19

Zdenka Ribarova - Slavomira Ribarova, Češka gramatika s vježbama, Zagreb: Porfirogenet, 2015,531 str.

Češka slovnica z vajami (Češka gramatika s vježbama) avtoric Zdenke in Slavomire Ribarove je v prvi vrsti univerzitetni učbenik, namenjen študentom bohemistike na Filozofski fakulteti Univerze v Zagrebu. Njegova pregledna podoba je lahko zanimiva tudi za vse, ki se želijo naučiti češkega jezika oziroma se poučiti o njem, z metodično znanstveno zasnovo, temelječo na sodobnih spoznanjih češke bohemistike, pa zagotovo lahko postane odličen vodnik za raziskovalce češkega jezik(oslovj)a in komparativiste tudi s širšega južnoslovanskega področja.

Ne gre za povsem novo delo, ampak za posodobljeno in nadgrajeno izdajo učbenika Pregled češke gramatike s vježbama avtorice Zdenke Ribarove, objavljenega prvič leta 1977 in nato (v nespremenjeni obliki) leta 1991. Ta že ima nesporno mesto $\mathrm{v}$ hrvaški bohemistični strokovni literaturi (kar dokazuje tudi potreba po novi izdaji), posodobitev gradiva pa zagotavlja njegovo uporabnost tudi za prihodnje generacije študentov češkega jezika in za zainteresirano javnost.

Učbenik ima klasično zasnovo, usmerjeno na dva večja tematska sklopa: glasoslovje s pravorečjem in pravopisom ter oblikoslovje, kamor je po češki jezikoslovni tradiciji uvrščeno tudi besedotvorje.

Prvi dve od skupno dvajsetih poglavij sta namenjeni glasoslovni problematiki s sistemizacijo čeških glasov in črk, zajeta je tudi obravnava naglasa in stavčne intonacije, $v$ pravopisu pa poleg tradicionalnih tem, kot so ločila (obravnavana je samo raba vejice), pisanje skupaj/narazen ter velika in mala začetnica, seveda tudi vse za češčino specifične (in za tujca, ki se uči tega jezika, pogosto tudi najtežje) teme, kot so pisanje mehkega in trdega $i$-ja $(i / y, i / y)$, označevanje dolžine samoglasnikov, pisanje ě in mehkih soglasnikov $(d,, t, \check{n})$ ter raba predlogov $s$ in $z$. Kot pomembno dodano vrednost je treba poudariti tudi uvrstitev tujk oziroma prevzetih besed tako $\mathrm{v}$ poglavje o pravorečju kot $\mathrm{v}$ tisto o pravopisu: klasični učbeniki češčine kot tujega jezika to sicer obravnavajo $\mathrm{v}$ oblikoslovnih poglavjih, le redko pa sta vanje vključena tudi izgovarjava in zapis teh izrazov. 
Naslednjih dvanajst poglavij (3.-14.) je posvečenih podrobni obravnavi češkega oblikoslovja, pri čemer tretje zajema kratek uvod v problematiko, v četrtem so predstavljeni osnovni načini tvorbe besed, v preostalih desetih pa so obravnavane posamezne besedne vrste. Pri samostalnikih, pridevnikih, glagolih in prislovih je vključeno tudi podpoglavje o njihovi tvorbi. Učbenik sicer ne zajema skladnje, je pa ta tematika vsaj delno pokrita v poglavju o veznikih (in zelo na kratko tudi pri rabi vejice v poglavju o pravopisu).

Pri obravnavi oblikoslovnih vprašanj morda najbolj stopa v ospredje dolgoletna pedagoška praksa obeh avtoric, ki je bila tudi metodološko izhodišče za pripravo učbenika. Poglavja so jasno strukturirana, pregledna, dodane so številne preglednice, na koncu vsakega poglavja pa najdemo tudi vaje, namenjene preverjanju razumevanja podane snovi. Drugo pomembno izhodišče pa je primerjalna struktura učbenika, ki obravnavana vprašanja ves čas umešča tudi v hrvaški jezikoslovni diskurz (naslovi posameznih podpoglavij učbenika so večinoma navedeni v obeh jezikih - hrvaškemu naslovu je dodan tudi češki prevod), kar bistveno olajša rabo tudi bolj laičnim bralcem, razlage pa so strukturirane tako, da opozarjajo na razlike med obema jezikoma oziroma na zahtevnejša mesta, na katera je treba biti pozoren. Tak pristop je zelo dragocen, saj je v češčini danes na oblikoslovnem področju veliko dvojnic, kjer si posamezne oblike konkurirajo med sabo, in je zato izbira zlasti za tujca, ki se uči češčine, lahko zelo zahtevna. Kot verjetno najboljši in najzahtevnejši zgled tega lahko navedemo obravnavo končnic v rodilniku in mestniku ednine za nežive samostalnike moškega spola s trdo osnovo - obravnava je podrobna, upošteva sodobna spoznanja češkega jezikoslovja, kljub temu pa ostaja pregledna in brez odvečnega zapletanja.

Morda najpomembnejši prispevek učbenika Češka gramatika s vježbama pa je 15. poglavje, ki obravnava češki neknjižni pogovorni jezik (t. i. obecná čeština). Avtorici že v uvodu knjige poudarjata pomembno značilnost kodifikacije češkega jezika, ki je že ob nastanku v času preroda temeljila na takrat dvesto let stari normi humanistične češčine. Posledica tega je velik prepad med standardno knjižno normo, zlasti v njeni pisani pa tudi govorjeni podobi (hovorová čeština), in nadnarečno (splošno) pogovorno neknjižno različico jezika. Ker je pojav opazen na vseh področjih vsakodnevne komunikacije, hkrati pa so razlike med knjižno in pogovorno češčino na oblikoslovnem področju takega tipa, da jih je mogoče sistemsko opisati, je uvrstitev tega poglavja v učbenik ključna, saj si uporabnik tako lahko ustvari celovito podobo sodobne češčine $\mathrm{z}$ njenimi najpomembnejšimi različicami.

V zvezi s 15. poglavjem je treba pohvaliti tudi odlično opravljeno delo na terminološkem področju. V ostalih poglavjih se je bilo mogoče zanesti na že uveljavljeno jezikoslovno izrazje tako v hrvaščini kot v češčini, različna socialna stratifikacija slovanskih jezikov pa pogosto povzroča težave pri poimenovanju posameznih socialnih zvrsti jezika. Avtorici sta se pri tem, kjer je bilo mogoče, oprli na obstoječo terminologijo, hkrati pa v skladu z njo izdelali tudi nekatera nova poimenovanja. 
Kot je že bilo omenjeno, učbenik odlikuje tudi zelo dobro izdelan metodološki aparat. Vsebuje več kot sto različnih preglednic in seznamov, med katerimi bodo učitelji in študentje morda najbolj cenili seznam zahtevnejših samostalnikov, ki imajo kakršne koli posebnosti v oblikoslovni paradigmi, in podobno tudi seznam zahtevnejših glagolov z vsemi njihovimi oblikami; ne eno ne drugo ni ravno pogosto sestavni del takšnih učbenikov. Ravno tako pomembni so tudi seznami besedotvornih pripon za tvorbo samostalnikov in pridevnikov, vključeni v ustrezni besedotvorni podpoglavji, poglavje o števnikih pa ponuja tudi obsežno preglednico glavnih in vrstilnih števnikov ter nadvse dragoceno preglednico osnovnih matematičnih izrazov, ki vključuje decimalna števila, ulomke, osnovne matematične operacije - vse to je lahko za tujca, ki se uči češčine, zelo trd oreh. Nekoliko preseneča dejstvo, da sta se avtorici pri predlogih odločili za abecedno obravnavo (enako tudi pri veznikih), a na koncu se izkaže, da je takšen pristop bolj pregleden, saj se izognemo iskanju enega veznika na različnih mestih (pri različnih sklonih ali pomenih). Posameznim poglavjem so dodane tudi dobro strukturirane vaje, iz katerih je prav tako razvidna dolgoletna praksa poučevanja češčine kot tujega jezika, saj so vaje usmerjene zlasti na mesta, ki bodo težavna ali zanimiva za hrvaškega uporabnika dela (npr. sklanjanje imen hrvaških mest).

Odlično metodološko zasnovo učbenika zaokroža zadnjih pet poglavij, ki vsebujejo:

- osnovno literaturo (poleg zelo podrobnega seznama češke bohemistične literature so v to poglavje vključeni tudi relevantni hrvaški viri, zlasti Babićeva Hrvatska gramatika iz leta 2005, na katero se učbenik terminološko opira);

- kazalo citiranih čeških besed, ki so v posameznih poglavjih podrobneje obravnavane, kar je lahko posebno dobrodošlo za morebitne laične uporabnike učbenika, ki bi se želeli poučiti o konkretnem problemu;

- kazalo čeških terminov, uporabljenih v učbeniku (to poglavje bi v prihodnjih izdajah morda kazalo razširiti v češko-hrvaški terminološki slovarček);

- obsežno stvarno kazalo;

- v 20. poglavju rešitve vaj.

Dejstvo, da Češka gramatika s vježbama gradi na tradiciji že uveljavljene hrvaške bohemistične literature in ima s tem zagotovljeno mesto na seznamih obveznega študijskega gradiva, v ničemer ne zmanjšuje pomena opravljenega dela. Avtorici hrvaški (in širši) javnosti ponujata odlično strukturiran, pregleden, terminološko dosleden, $\mathrm{z}$ najsodobnejšimi bohemističnimi spoznanji dopolnjen in $\mathrm{v}$ hrvaški jezikoslovni diskurz vpet priročnik, ki bo zagotovo pomemben spremljevalec vsakogar, ki se bo odpravil na pot spoznavanja enega najtežjih slovanskih jezikov. 